\title{
Upaya Pengawas Dalam Meningkatkan Kemampuan Profesional Guru Melalui Supervisi Klinis Pada SMA Negeri Di Manado
}

\author{
Virginia H Saneba1, Joulanda A.M Rawis ${ }^{2}$, Mozes Markus Wullur ${ }^{3}$ Viktory N.J. Rotty ${ }^{4}$ \\ 1,2,3,4Universitas Negeri Manado, Indonesia \\ 1ginasaneba@yahoo.com; 2joulandarawis@unima.ac.id; 3mozeswullur@unima.ac.id; “Viktoryrotty@unima.ac.id \\ *ginasaneba@yahoo.com
}

\section{KATA KUNCI}

Keterampilan, Profesional,

SMA,

Supervisi Klinis,

Supervisor,

\section{KEYWORDS}

Clinical Supervision, professional skills, Senior High School Supervisor,
ABSTRAK

Belum optimalnya fungsi supervisi klinis di SMA Negeri 10 Manado mendorong peneliti untuk mengklarifikasi masalah agar mendapatkan gambaran yang jelas tentang pelaksanaan supervisi klinis instruktur. Pendekatan dalam penelitian ini adalah kualitatif naturalistik (Bogdan dan Biklen, 1982). Kegiatan supervisi klinis oleh supervisor membantu guru memecahkan masalah pembelajaran yang berdampak positif terhadap kinerja guru. Hasil menunjukkan bahwa upaya pengawas mata pelajaran untuk meningkatkan keterampilan profesional guru SMA Negeri 10 Manado untuk guru mata pelajaran sangat baik. Hal ini terlihat dari rencana/program pengawasan yang dikembangkan dan pembinaan yang diberikan kepada dosen di bidang kualifikasi masing-masing, tanpa hasil yang signifikan, namun dosen pembimbing yang diteliti memberikan pengawasan klinis. belum cukup dilaksanakan sesuai tahapan supervisi klinis, namun supervisi klinis supervisor subjek penelitian berpengaruh kecil terhadap sivitas akademika SMA Negeri 10 Manado. 10 topik penelitian keterampilan profesional guru SMA negeri belum diteliti secara menyeluruh, ya memenuhi kriteria pendidik dan tenaga kependidikan.

\section{Supervisor's Efforts in Improving Teacher Professional Ability Through Clinical Supervision at Public Senior High Schools in Manado}

The not yet optimal function of clinical supervision at SMA Negeri 10 Manado encourages researchers to clarify the problem in order to get a clear picture of the implementation of instructor clinical supervision. The approach in this research is qualitative naturalistic (Bogdan and Biklen, 1982). Clinical supervision activities by supervisors help teachers solve learning problems that have a positive impact on teacher performance. Results shows that the efforts of subject supervisors to improve the professional skills of SMA Negeri 10 Manado teachers for subject teachers are very good. This can be seen from the supervision plans/programs that were developed and the guidance given to lecturers in their respective qualification fields, without significant results, but the supervisors studied provided clinical supervision. it has not been sufficiently implemented according to the clinical supervision stage, but the clinical supervision of the research subject supervisor has little effect on the academic community of SMA Negeri 10 Manado. The 10 topics of 
research on the professional skills of public high school teachers have not been thoroughly researched, so they meet the criteria for educators and education staff.

This is an open-access article under the CC-BY-SA license.

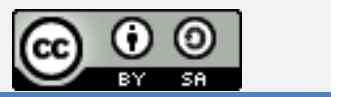

\section{Pendahuluan}

Sebagai salah satu upaya optimalisasi proses pembelajaran pendidikan menengah (SMA), seluruh pendidik setingkat SMA membutuhkan penyuluhan yang terarah dan berkelanjutan dengan program yang terukur dan sistematis. Program pengembangan untuk menyelenggarakan pendidikan sering disebut dengan supervisi (supervisi pendidikan). Pengawasnya adalah Peraturan Menteri Negara (Kep. MENPAN) No. tentang Penggunaan Perlengkapan Negara dalam Melakukan Kegiatan Kepemimpinan. Lihat 118/1996. Menurut pengertian ini pengawas sekolah adalah pegawai negeri sipil yang dilimpahkan segala tugas oleh pejabat yang berwenang. Tanggung jawab dan wewenang mengawasi penyelenggaraan pendidikan di sekolah umum dengan memberikan penilaian dan bimbingan teknis di bidang pendidikan dan manajemen di satuan prasekolah seperti sekolah, sekolah dasar, sekolah menengah pertama, dan sekolah menengah atas. Undang-Undang Republik Indonesia Nomor 14 Tahun 2005 tentang Guru dan Guru dan Peraturan Pemerintah Nomor 74 Tahun 2008 tentang Guru dalam Bab 1 Ayat 1 Ayat 1 menyatakan: Tugas-tugas tersebut adalah pembinaan siswa, pendidikan, bimbingan, kepemimpinan, pelatihan, evaluasi dan evaluasi dalam pendidikan anak usia dini, pendidikan formal, pendidikan dasar dan menengah. Sebagai pendidik profesional, guru memegang peranan yang sangat besar dan strategis dalam mencapai tujuan pendidikan nasional.

Guru berkewajiban membuat perencanaan pembelajaran sebelum dilaksanakan kjewajiban profesionalannya sebagai guru dan wajib merancang pembelajaran, melakukan aktifitas belajar berualitas, melakukan penilaian dan evaluasi hasil pembelajaran. Sejalan dengan Undang-undang Republik Indonesia dalam mengemban misi profesi, guru berkewajiban menyusun rencana pembelajaran, dan guru juga berkewajiban menyusun rencana pembelajaran, menyelenggarakan aktifitas belajar yang berkualitas, serta mengevaluasi hasil pembelajaran. Hal ini sesuai dengan Undang-Undang tentang Guru dan Guru Republik Indonesia Tahun 2005 No. 14. Penelitian ini berfokus pada bidang-bidang utama penelitian berikut ini: Bidang studi utama: SMA Negeri 10 Sekilas tentang upaya supervisor sebelumnya untuk meningkatkan keterampilan profesional guru, langkah yang diambil supervisor untuk pelaksanaan supervisi klinis, dan akibat supervisi klinis. Aktifitas ini dikerjakan oleh pengawas guru Negeri 10 Manado, prospek peningkatan profesional guru SMA Negeri 10 Manado saat ini dan masa depan. Tujuan utama dari penelitian ini adalah untuk meningkatkan keterampilan profesional guru SMA Negeri 10 Manado melalui supervisi klinis, dan penelitian ini secara khusus berkaitan dengan upaya sebelumnya 
oleh pengawas untuk meningkatkan keterampilan profesional SMA.Tujuannya adalah untuk memberikan informasi. Menemukan dan menganalisis Guru Negeri 10 Manado. Tahapan yang dilakukan supervisor saat melaksanakan supervisi klinis, akibat supervisi klinis pengawas terhadap guru SMA Negeri 10 Manado.

\section{Metode}

Metode yang digunakan pada penelitian ini yaitu kualitatif naturalistik (Bogdan dan Biklen, 1982), dengan menggunakan tujuan penelitian SMA Negeri 10 Manado. Untuk mengikuti pendekatan dan tujuan penelitian, dan untuk membuat penelitian ini lebih tepat sasaran. Enam guru dari SMA Negeri 10 Manado dipilih sebagai topik penelitian. Mengidentifikasi upaya supervisor dalam meningkatkan keterampilan profesional guru SMA Negeri 10 Manado, langkah supervisor saat melaksanakan supervisi klinis, akibat pengawasan terhadap supervisi klinis pada guru SMA Negeri 10 Manado, prospek pengembangan profesional sekarang dan masa depan SMA Negeri 10 Manado guru.

\section{Hasil dan Pembahasan}

\section{Usaha yang Dilakukan Pengawas guna peningkatan kompetensi Profesional Guru SMA}

a. Perencanaan program kepengawasan

Misi pengawas sekolah secara umum terdiri dari identifikasi masalah, pengembangan program pengawasan, pelaksanaan pengawasan, evaluasi dan analisa dari hasil pengawasan, dan pembinaan dilakukan berdasarkan hasil penilaian. Berdasarkan penugasan dan fungsi , sudah seharusnya pengawasan ditempatkan pada perencanaan aktifitas operasional, sering disebut sebagai rencana tindakan, pengawasan untuk memperbaiki situasi pendidikan secara umum, dan situasi pendidikan dan pembelajaran (Sutisna, 1986). Ali Imron menyatakan bahwa supervisi merupakan rangkaian dukungan terhadap guru, terkhusus melalui pelayanan profesional dalam rangka peningkatkan proses pendidikan dan pembelajaran. Selain itu, Sahertian berasumsi bahwa supervisi adalah layanan dan dukungan untuk memacu mutu pendidikan. Untuk meningkatkan efisiensi dan efektivitas pengelolaan sistem perencanaan supervisi merupakan salah satu fungsi yang paling strategis, dan bermacam medote dapat diterapkan untuk mencegah kemungkinan peluang di masa depan. Dalam hal ini, Cunningham (1982), melalui perencanaan, memungkinkan pengambilan keputusan untuk memandang lebih jauh ke masa depan dalam rangka antisipasi berbagai peristiwa, merancang kesempatan berbeda, dan membuat instruksi untuk mencapai tujuan mereka.Ini menjelaskan bahwa Anda dapat membuat kartu aktivitas dan menyiapkan set yang berbeda dari instruksi. Alasan penting mengapa suatu rencana harus 
dilaksanakan dalam kegiatan pengawasan adalah sebagai berikut: 1) Menemukan kredibilitas fakta yang diperoleh dan disajikan sehingga berbagai pihak yang berkepentingan dengan hasil pengawasan yang dilakukan dapat menerimanya. 2) Data obyektif diperoleh dari hasil yang diperoleh dari kegiatan pengawasan yang direncanakan 3) Pengawasan dirancang secara baik dan melibatkan kewajaran dan obyektif 4) Kegiatan pengawasan yang terencana adalah latar belakang, aktifitas yang sepenuhnya menyadari tujuan dan prosedur 5) Program atau terencana pengawasan dapat digunakan sebagai komponen integral dan global dari pengembangan pendidikan umum, khususnya pengembangan sekolah, untuk semua orang yang terlibat, Anda dapat langsung melihat manfaatnya.

Setiap pengawas sekolah harus memiliki rencana kegiatan untuk mencapai tujuan pengawasan yang diharapkan. Artinya, pengawas (i) mengidentifikasi problem dari hasil supervisi tahun sebelumnya dari kegiatan supervisi sekolah (ii) menyusun pedoman kerja untuk mengetahui dengan jelas apa yang harus dilakukan, (iii) supervisi Rencana kerja seseorang (iv) Untuk mengevaluasi atau mengevaluasi efektivitas rencana program pengawasan.

\section{b. Pelaksanaan Pengawasan}

Aktifitas yang wajib dilakukan oleh pengawas adalah (i) menasihati guru, direktur sekolah dan staf kependidikan di wilayah binaan, dan (ii) menilai nilai guru, nilai kepala sekolah, dan nilai seluruh staf sekolah. (iii) mengevaluasi dan memantau pelaksanaan dan pengembangan program sekolah. Kegiatan pembinaan khususnya keterampilan guru dalam pengelolaan KBM harus dilakukan secara berkesinambungan oleh pengawas yang bertanggung jawab. Oleh karena itu, keberhasilan seorang guru melaksanakan KBM bergantung sepenuhnya pada derajat keterlibatan peran dan fungsi pengawas itu sendiri. Supervisi memiliki fungsi utama yaitu memperbaiki dan meningkatkan proses pendidikan dan pembelajaran guru sekolah. Dalam konteks ini, terdapat tiga fungsi utama pengawasan kinerja guru dalam KBM yang menurut Malik.

Supervisi kurikulum berfungsi untuk menjamin penyampaian kurikulum sesuai sasaran, membantu guru merencanakan program akademis guna perbaikan proses KBM, pelaksanaan program pengajaran untuk pengembangan profesi, Pemantauan kurikulum untuk memastikan implementasi kurikulum yang sesuai, meningkatkan proses pembelajaran dengan membantu guru merencanakan program akademik mereka.

Pengembangan keprofesian dalam penyelenggaraan program pendidikan lahir pada tahun . Kemampuan guru sekolah dalam KBM adalah penguasaan materi, metode, alat, dan penilaian. Keempat indikator tersebut tidak berdiri terpisah, tetapi saling terkait dan mempengaruhi satu sama lain. Guru sebagai pendidik tidak hanya berkepentingan untuk memberikan pengetahuan, tetapi juga pada pertumbuhan pribadi siswa dan pembentukan nilai etika dan estetika dalam menyambut tantangan masa depan di masyarakat. Sahertian berkata: "Fungsi utama supervisi 
tidak hanya untuk meningkatkan pembelajaran, tetapi juga untuk mengkoordinasikan, menginspirasi dan mendorong pertumbuhan profesi guru." Jika anda menganggap supervisor/supervisor sebagai penjamin mutu pendidikan. Ini sesuai dengan pernyataan (Sallis, 1994), bahwa "fungsi penjaminan mutu bagi siswa, orang tua, masyarakat, pemerintah, dan dunia kerja sebagai pelanggan pendidikan yang diakibatkan oleh tidak memadainya pendidikan". Pelaksanaan supervisi secara tradisional terdiri dari tahapan berikut: (a) menetapkan kriteria untuk mengukur kinerja, (b) kinerja Pengukuran, (c) analisis apakah kinerja memenuhi kriteria, (d) kinerja tidak memenuhi kriteria tindakan (Nanang Fatah, 1996: 102).

\section{c. Evaluasi dan Hasil Pengawasan Tindak Lanjut}

Terdapat langkah - langkah pengawasan yang wajib dilakukan pengawas yaitu perencanaan, persiapan, pengawasan, pasca evaluasi dan follow up, serta pembinaan dan pemantauan terhadap seluruh elemen pada sistem pendidikan sekolah binaan. Kumpulkan data tentang wawasan lapangan dan proses serta analisis data tersebut. Ini dibutuhkan agar dapat mengetahui ketercapaian kewajiban pengawasan dalam peningkatan kualitas proses pendidikan dan hasil di sekolah sasaran dan untuk mengukur efektivitas pengawasan yang dilakukan untuk penerus masa depan. Tentang kegiatan pembinaan di masa depan. Dukungan tindak lanjut didasarkan pada hasil penilaian komprehensif dari semua kegiatan surveilans. Tujuan utama evaluasi adalah (a) untuk mengetahui sejauh mana pelaksanaan program, (b) untuk mengetahui keberhasilan program, (c) memperoleh bahan/masukan untuk merancang program tahun depan, dan (d) Evaluasi (evaluasi) sekolah. Suhardan (2010:188) menyatakan bahwa menilai aktifitas kepengawasan adalah cara agar mengetahui sejauh mana keefektifan dukungan.

\section{Pengawas dengan cara yang ditempuh}

Dalam supervisi klinis, supervisor memiliki peran penting. 1) Peran kemitraan. Dengan kata lain, kepala sekolah dan guru paling memahami kondisi sekolah, sehingga supervisor bekerja sama dengan kepala sekolah dan guru. 2) Sebagai atasan, yaitu ada beberapa hal dalam kegiatan manajemen dengan fungsi organik, dalam supervisi klinis, supervisor memiliki peran penting. 1) Peran kemitraan. Dengan kata lain, kepala sekolah dan guru paling memahami kondisi sekolah, sehingga supervisor bekerja sama dengan kepala sekolah dan guru. 2) Sebagai bos, yaitu ada beberapa fungsi organik dalam kegiatan manajemen, adalah fungsi yang tidak dapat dipisahkan dari aktifitas manajemen 3) Sebagai Pembina, artinya supervisor adalah pekerja yang profesional, maka tugas utama supervisor adalah memberikan bimbingan kepada guru. 4) Sebagai motivasi. Artinya pengawas selalu mendorong guru baik untuk pengembangan diri maupun pengembangan kemitraan dengan pengawas, kepala sekolah, dan guru lainnya. 
Pendekatan kolaboratif dan pendekatan religi adalah pendekatan yang perlu dilakukan pengelola. Model pendekatan kolaboratif adalah model yang menekankan kemitraan antara supervisor dan individu atau kelompok yang dirawat untuk melakukan supervisi klinis yang penyajiannya sebagai berikut: pertama seorang manajer bertindak sebagai mitra atau karyawan selanjutnya mereka saling berbagi pengalaman dan pengetahuan , ketiga pendekatan eksplorasi diusulkan maknanya untuk menyelidiki kondisi individu atau kelompok yang dipantau kemudian untuk membantu guru dan direktur madrasah menjadi tenaga kependidikan yang professional supervisi dilakukan. Akan tercipta suasana akrab dan terbuka di antara orang-orang dan kelompok yang merawatnya karena pendekatan kolaboratif dalam melakukan supervisi klinis sangat relevan. Disamping itu pendekatan religi yang mengedepankan nilai-nilai agama sebagai dasar pemenuhan tugas supervisi dapat digunakan. Sebagai contoh, Nurtain (1998) menyatakan bahwa terdapat tujuh prinsip yang harus diikuti supervisor saat melakukan tugas supervisi klinis. Yang dapat dijelaskan sebagai berikut : pertama harus berpusat pada guru, adanya keterhubungan guru-penyelia yang lebih interaktif daripada instruksi, menumbuhkan sikap berwibawa yang demokratis , umpan balik langsung dari proses pembelajaran guru, atau untuk tujuan meningkatkan kompetensi pendidikan dan prilaku profesional guru, fokus direktur. Supervisi klinis adalah proses siklus. Hal ini sesuai dengan pendapat Acheson dan Gali (1992:11) bahwa supervisi klinis terdiri dari tiga fase: (a) fase sesi pertama/pra-observasi, (b) fase observasi kelas, dan (c). Fase umpan balik. 1) Tahap wawancara awal

Pada tahap wawancara awal atau observasi pendahuluan, supervisor dan guru berdialog untuk mencapai kesepakatan bersama. a) Mengidentifikasi masalah dan kendala yang guru hadapi dan alami saat melakukan KBM, serta penyebab yang merupakan factor-faktor utama. Pada fase terakhir ini, supervisor dan guru mengembangkan persoalan dan solusi yang tentunya secara bersama-sama disepakati . b) Diskusi beberapa alternatif jenis perilaku belajar yang dilakukan Pengawas dan guru untuk memecahkan masalah. Pengawas dan guru harus memilih dan memutuskan salah satu cara yang akan digunakan guru untuk memecahkan masalah dari hasil tersebut. c) Sebagai moderator Guru dengan didukung supervisor menyelenggarakan program tindakan pembelajaran dengan unsur-unsur sebagai berikut: Saya mendidik dan perlu meningkatkan proses belajar saya. d) Guru dan pengawas sekolah menentukan kriteria keberhasilan kegiatan pembelajaran yang dilakukan di kelas di mana guru bertanggung jawab untuk meningkatkan proses pembelajaran. e) Guru dan supervisor mengembangkan alat untuk. Pedoman observasi kemampuan guru mengajar dan tingkat keberhasilan proses pembelajaran yang dilakukan guru diukur, diukur dengan tes dan hasil belajar siswa. f) Mengukur kemampuan guru dalam mengajar, proses pembelajaran dan prestasi belajar siswa, menyusun catatan kegiatan guru oleh supervisor, mempraktekkan program kegiatan guru yang disusun untuk menetapkan jadwal pelaksanaan Penggunaan alat bantu. 


\section{Tahap Observasi Kelas}

Pada awal pertemuan jadwal direncanakan, langkah kedua dari supervisi klinis yaitu guru melakukan aktifitas mengajar dan pengawas melakukan pengamatan prilaku guru dalam proses melaksanakan pembelajaran. Aktifitas yang dilakukan oleh guru dan pengawas dapat dijelaskan berikut ini: Pertama guru melakukan aktifitas KBM sesuai RPP yang disusun di awal pertemuan. Aspek-aspek yang dirasa paling lemah menjadi pusat perhatian guru pada prktek mengajar adalah, 2) Cara guru mengajar dikelas diperhatikan meliputi aktifitas belajar siswa, 3) setelah guru selesai melakukan tindakan pembelajaran, pengawas menceimati dan menilai hasil rekaman guru mengajar, hasil pengamatan, hasil belajar siswa serta Sesuai jadwal yang telah ditetapkan pada wawancara pertama, langkah kedua supervisi klinis adalah mengamati perilaku guru saat guru mengajar dan supervisor melakukan proses pembelajaran. Kegiatan kedua belah pihak adalah sebagai berikut. 1) Guru mengambil perilaku belajar berdasarkan program yang telah disiapkan pada pertemuan pertama. Oleh karena itu, fokus perhatian guru dalam praktik pendidikan ini adalah pada apa yang dianggap paling lemah. 2) Pengawas mengamati perilaku guru di kelas dan mengamati proses belajar siswa serta peralatan lembar observasi yang dibuatnya. 3) Setelah guru menyelesaikan perilaku belajar, supervisor mengamati dan mengevaluasi rekaman dialog dengan guru tentang bimbingan guru, observasi, hasil belajar siswa, dan kesan guru selama perilaku pembelajaran. Hal ini dilakukan untuk mengkonfirmasi keberhasilan tindakan guru dalam memperbaiki dan mengatasi masalah pembelajaran. 4) Tetapkan kegiatan umpan balik, atau jadwal untuk pertemuan berikutnya, untuk melacak dan mengamati perilaku guru saat melakukan pembelajaran lanjutan.

\section{Tahap Pertemuan Balikan}

a. Sesi umpan balik

adalah tahap akhir dari proses supervisi klinis yang dilakukan oleh supervisor dan guru yang disupervisi untuk menganalisis hasil perilaku guru dan menentukan bagaimana guru dapat memecahkan masalah pembelajaran. ditindak lanjuti oleh guru mata pelajaran, supervisor klinis dan guru berusaha untuk mengawasi data dan informasi dari data yang direkam dari pengamatan yang dianalisis, Anda akan diminta untuk melakukan Cecen Sumarna). Auditor sekolah dan guru, bersama dengan guru, sampai pada kesimpulan bahwa peningkatan pembelajaran dapat dicapai dengan menerapkan perilaku belajar yang dipraktikkan. Dengan kata lain, perilaku belajar yang diupayakan guru dapat dijadikan sebagai cara kerja guru dalam melakukan proses pembelajaran selanjutnya. Dan supervisor harus senantiasa memantau dan memotivasi guru agar tidak mengulangi kesalahannya dalam melakukan pekerjaan profesionalnya. Selain langkah-langkah yang harus dilakukan supervisor dalam melakukan supervisi klinis ini, ada beberapa 
pendekatan/teknik yang harus dilakukan supervisor. Artinya, (1) peran kemitraan. Dengan kata lain, atasan bekerjasama dengan kepala sekolah dan guru sekolah. Untuk memitigasi permasalahan yang muncul, kami akan membangun kemitraan berdasarkan kebutuhan dan saling pengertian dari kedua belah pihak dan meningkatkan rasa tanggung jawab atas keberhasilan program yang telah disepakati. (2) Peran motivasi. Artinya, sebagai motivasi/dorongan bagi guru untuk terus mengembangkan wawasan dan keterampilan profesional serta meningkatkan kreativitasnya.

\section{b. Dampak Supervisi Klinis Pengawas Terhadap Guru SMA}

Observasi klinis merupakan bentuk pelayanan yang diberikan oleh kepala sekolah kepada guru yang mengalami kesulitan/masalah belajar. Oleh karena itu, supervisi klinis harus dilakukan dengan baik oleh kepala sekolah, yang berdampak positif bagi pengembangan profesional guru. Dalam supervisi klinis, kegiatan supervisi klinis supervisor bagi guru terutama adalah supervisi dan penunjang operasional dalam pembelajaran guru, bukan perintah atau instruksi, sehingga diperlukan penyebab dan pemecahan masalah. Artinya, kegiatan supervisi klinis yang dilakukan supervisor terhadap guru diciptakan semata-mata untuk tanggung jawabnya untuk meningkatkan kualitas guru. Pengembangan keterampilan profesional guru di sekolah khususnya di tingkat sekolah menengah sangat penting dan menitikberatkan pada peningkatan mutu pendidikan yang diharapkan.Meningkatkan mutu guru, pengawas sekolah dan masyarakat umum.Perhatian khusus dari organisasi terkait diperlukan. Oleh karena itu, guru dapat memecahkan masalah dengan sentuhan bimbingan dan supervisi, mandiri dan memiliki tingkat kreativitas yang tinggi, sehingga pengawas yang profesional dapat melaksanakan tugasnya dengan baik dan profesional, diharapkan dapat memikul tanggung jawab yang besar atas pekerjaan yang baik, motivasi yang tinggi dan memadai. inovasi.

\section{c. Perspektif Peningkatan kemampuan Profesional Guru SMA}

Keberhasilan sekolah di masa depan dapat diukur dari derajat kompetensi profesional guru dalam mengelola pembelajaran. Oleh karena itu, guru harus memiliki kompetensi. rencana pelatihan, pelaksanaan pelatihan dan di masa depan, keberhasilan sekolah dapat diukur dari sejauh mana keterampilan profesional guru mengelola pembelajaran. Oleh karena itu, guru perlu memiliki keterampilan merencanakan pembelajaran, melaksanakan pembelajaran, dan melakukan penilaian secara benar untuk mengukur keberhasilan proses belajar mengajar. Ketiga keterampilan dasar tersebut harus dimiliki oleh guru dan harus selalu dikembangkan oleh guru. Oleh karena itu, guru ML harus memiliki standar pendidikan, antara lain standar latar belakang pendidikan (minimal S1), standar kompetensi (kemampuan pendidikan, personal, sosial, profesional) dan sertifikat pendidik. Hal ini sesuai dengan UU No. 14 Bab IV, Pasal 8 Tahun 2005 
UU Guru dan Guru, yang menyatakan: Guru harus memiliki latar belakang pendidikan, kemampuan, ijazah pendidikan, kesehatan jasmani dan rohani, serta kemampuan untuk mencapai tujuan pendidikan nasional. Berdasarkan kenyataan bahwa situasi guru sekolah menengah saat ini belum sepenuhnya memenuhi standar hukum di bidang pendidikan dan bahwa ada prospek peningkatan kemampuan vokasional guru sekolah menengah di masa depan, ketua POKJA (Pokja ) Kota Manado berkata: Dikatakan. Dengan perkembangan dan kemajuan ilmu pengetahuan dan teknologi (iptek), keterampilan guru sekolah menengah perlu lebih ditingkatkan karena tugas sehari-hari guru yang sulit dan kompleks semakin kompleks. Untuk meningkatkan dan mengembangkan keterampilan profesional guru SMA, menggunakan kemampuan guru, kurikulum, isi kemampuan menggunakan metode dan media pengajaran dalam pengajaran, pendidikan dan pelatihan, lingkungan sebagai sumber belajar, dan pemenuhan tugas guru. berusaha keras. Kualifikasi profesional guru dalam profesi guru dapat ditemukan pada empat unsur keterampilan inti. Kemampuan merencanakan kurikulum, kedua, kemampuan menerapkan kurikulum, ketiga: kemampuan mengevaluasi kemajuan belajar dan proses pembelajaran, keyakinan dan persepsi guru tentang profesinya, perkembangan dan kemajuan perhatian siswa, dan pendidikan guru Kegiatan keterampilan dan pelatihan lainnya untuk membantu Anda berpartisipasi dalam

\section{Simpulan}

Hasil dari penelitian ini dapat disimpulkan sebagai berikut: 1) Upaya pembimbing subjek penelitian untuk meningkatkan kemampuan profesional dosen sasaran penelitian SMA Negeri 10 Manado sangat baik. Hal ini terlihat dari rencana/program pengawasan yang dikembangkan, dan meskipun tidak menunjukkan hasil yang signifikan, namun pembinaan diberikan kepada guru di wilayah binaannya masing-masing. 2) Supervisi klinis oleh pembimbing penelitian belum optimal Menjelaskan supervisi pembimbing topik penelitian dan tidak dilakukan oleh pembimbing sesuai prosedur yang akan dilakukan, 3) Pembimbing topik penelitian Langkah-Langkah Melakukan Supervisi Klinis Instruktur yang diteliti tidak sepenuhnya dilaksanakan sesuai dengan tahapan supervisi klinis, , tetapi guru bertanggung jawab atas administrasi pengajaran / peralatan pembelajaran dalam menjalankan misi profesionalnya 5) Perspektif Meningkatkan profesionalisme sekolah menengah guru, topik penelitian tidak sebaik orang suci. Temui Andard yang penuh dengan pendidik dan tenaga kependidikan.

\section{Daftar Pustaka}

Acheson,K.A and Gall,M.D. (1980). Techniques in the Clinical Supervision of Teachers, 3d ed. New York: Longman

Ali Imron. (1995). Pembinaan Guru di Indonesia, Jakarta: Dunia Pustaka Jaya, hal. 10. 
Bogdan, Robert C. dan Biklen Kopp Sari (1982). Qualitative Research for Education: An Introduction to Theory and Methods. Allyn and Bacon, Inc.: Boston London.

Cunningham, William G.(1982).Systemmatic Planning for Educational Change, $1^{\text {st }}$ Edition. California: Mayfield Publishing Company.

Departemen Agama RI (2006), Model-model Pelatihan Bagi Pengawas Sekolah, Jakarta: Dirjen Kelembagaan Agama Islam

Departemen Pendidikan Nasional. (2007), Peraturan Menteri Pendidikan Nasional (PERMEN DIKNAS) nomor 16 Tahun 2007 Tentang Standar Kualifikasi Akademik dan Kompetensi Guru

Fattah, Nanang, Landasan Manajemen Pendidikan, (Bandung: PT Remaja Rosdakarya, 1996)

Hamzah. (2008), Profesi Kependidikan, Jakarta: Bumi Aksara.

Kunandar, (2007), Guru Profesional, Jakarta : PT Raja Grafindo Persada

Musiich Mansur, (2007), Sertifikasi guru Menuju Profesionaliasi Pendidik, Jakarta: Bumi Aksara.

Nurtain. (1989). Supervisi Pengajaran (Teori dan Prektek). Jakarta: Depdikbud, Dirjen Dikti P2LPTK.

Oteng Sutisna (1986). Administrasi Pendidikan . Bandung : PT Angkasa

Purwanto Ngalim, (2007), Administrasi dan Supervisi Pendidikan, Bandung: remaja Rosda

Karya. Makalah Pengawasan Pendidikan di Sekolah. SPs-UPI.

Sahertian Piet A (2008), Konsep dasar \& Teknik Supervisi pendidikan, Jakarta: Rineka Cipta.

Sallis Edward (2006). Total Quality Management in Education. Jogjakarta:IRCiSoD.

Suhardan, Dadang. 2010. Supervisi Profesional. Alfabeta. Bandung

Surat Keputusan Menteri Negara Pendayagunaan Aparatur Negara (Kep. MENPAN) No. $118 / 1996$

Tilaar, H.A.R. (2004), Paradigma Baru Pendidikan Nasional, Jakarta: Rineka Cipta Uno B.

UU No. 14 tahun 2005 tentang Guru dan Dosen.

Wahyudi. (2009), Kepemimpinan Kepala Sekolah Dalam Organisasi Pembelajaran (Learning Organitation), Bandung: Alfabeta. 